\title{
Application Of Mathematical Literacy In Mathematics Learning For Elementary School
}

\author{
Dina Fitria ${ }^{1}$, Fadhilah Fitri ${ }^{1 \#}$, Fridgo Tasman', Defri Ahmad ${ }^{1}$, Suherman ${ }^{1}$ \\ ${ }^{1}$ Jurusan Matematika Universitas Negeri Padang Jln Prof Dr Hamka Air Tawar Padang, 25131, Indonesia \\ \#Correspondence: fadhilahfitri@fmipa.unp.ac.id; Tel.: +62822 84993365
}

Diterima 17 September 2019, Disetujui 1 November 2019, Dipublikasikan 30 November 2019

\begin{abstract}
Mathematical literacy requires individuals to solve a problem and also apply mathematics in everyday problems, which results in the ability to interpret solutions to those problems. In PISA it is known that Indonesia's mathematics literacy score is among the lowest, as well as in Guguak District Lima Puluh Kota Regency. One way to overcome this is to start introducing literacy to students early on. The introduction of literacy must be instilled in students since they are still in elementary school. Based on this, a training program and workshop was held regarding the application of mathematical literacy in mathematics learning in elementary schools in Guguak District with elementary school mathematics teacher partners who are members of the Teachers Group Work (KKG) SD Gugus III Guguak District, Lima Puluh Kota Regency.
\end{abstract}

Keywords: elementary school, mathematical literacy, mathematics learning

This is an open access article distributed under the Creative Commons 4.0 Attribution License, which permits unrestricted use, distribution, and reproduction in any medium, provided the original work is properly cited. C2017 by author and Universitas Negeri Padang.

\section{Pendahuluan}

Literasi matematika dalam PISA (Programe for International Students Assesment) merupakan kemampuan siswa dalam menganalisa, memberi alasan dan menyampaikan ide secara efektif, merumuskan, memecahkan, dan menginterpretasi masalah matematika dalam berbagai bentuk dan situasi [1]. Hal ini menunjukkan bahwa literasi matematika tidak hanya menuntut individu untuk menyelesaikan suatu masalah tetapi juga menerapkan ilmu matematika dalam permasalahan sehari-hari. Adapun puncaknya adalah mampu menginterpretasi penyelesaiaan dari permasalahan tersebut.

PISA merupakan suatu penilaian secara international terhadap keterampilan dan kemampuan siswa usia 15 tahun [2]. Prestasi/ penilaian yang diukur pada PISA meliputi prestasi literasi membaca, matematika dan sains [3]. Penilaian terhadap ketiga bidang ini dilakukan berdasarkan soal tes yang dikoordinasi oleh OECD (Organisation for Economic Cooperation and Development). Indonesia telah berpartisipasi sebanyak enam kali dalam kegiatan
PISA ini, yaitu tahun 2000, 2003, 2006, 2009, 2012 dan 2015 [4]. Berdasarkan hasil yang diperoleh rata-rata skor peserta Indonesia selalu berada jauh di bawah rata-rata dari keseluruhan peserta (internasional) dan dari segi peringkat Indonesia juga selalu berada pada 10 negara peserta dengan skor literasi matematika terendah. Hal ini juga terjadi di Kabupaten Lima Puluh Kota khususnya Kecamatan Guguak. Berdasarkan hal ini diperlukan suatu tindakan untuk mengatasinya terutama melalui guru.

Salah satu upaya untuk mengatasi hal tersebut adalah memulai mengenalkan tentang literasi kepada siswa sejak dini. Pengenalan literasi harus ditanamkan kepada siswa semenjak mereka berada di sekolah dasar. Dengan pengenalan literasi kepada siswa di sekolah dasar diharapakan mereka dapat memantapkan menguatkan pengetahuan mereka tentang matematika lebih baik lagi pada jenjang pendidikan selanjutnya. Berdasarkan observasi lapangan, guru-guru matematika SD di Kecamatan Guguak belum mengenal dengan baik apa itu literasi dan bagaimana cara 
mengimplementasikannya pada pembelajaran matematika sekolah dasar terlebih lagi dalam pembelajaran mereka sudah diharuskan menerapkan pembelajaran scientifik.

Pengetahuan yang rendah tentang literasi diperparah dengan anggapan siswa tentang pembelajaran matematika. Siswa di kecamatan ini menganggap matematika adalah pembelajaran yang bersifat abstrak karena terlalu banyak formula yang harus mereka ketahui tanpa tau darimana formula tersebut berasal. Sehingga diperlukan suatu pelatihan dan workshop penerapan literasi matematika dalam pembelajaran matematika di sekolah dasar, khususnya Kecamatan Guguak Kabupaten Lima Puluh Kota.

Berdasarkan hal tersebut maka dilaksanakannya program kegiatan pelatihan dan workshop penerapan literasi matematis dalam pembelajaran matematika di sekolah dasar di Kacamatan Guguak Kabupaten Lima Puluh Kota dengan mitra guru-guru matematika Sekolah Dasar yang tergabung pada KKG SD gugus III Kecamatan Guguak Kabupaten Lima Puluh Kota.

\section{Solusi/Teknologi}

Atas dasar permasalahan yang dihadapi mitra yang dipaparkan pada bagian pendahuluan, beberapa alternatif solusi yang dapat ditawarkan adalah sebagai berikut.

1. Menambah pengetahuan para guru Sekolah Dasar tentang Literasi Matematika agar dapat memfasiltasi siswa belajar.

2. Menambah wawasan para guru SD Kecamatan Guguak Kabupaten Lima Puluh Kota merancang soal-soal yang dapat mengases tentang literasi matematika sehingga dapat meningkatkan mutu pendidikan matematika di Indonesia umumnya dan di Kecamatan Guguak khususnya.

Berdasarkan hal ini, dilaksanakan pelatihan dan workshop berkaitan dengan literasi, yang dimulai dengan pengenalan literasi sekolah yang merupakan program nasional yang diluncurkan Kementrian Pendidikan. Kemudian, dilanjutkan dengan literasi matematis, bagaimana konsep dan penggunaannya dalam pembelajaran. Guru diajak merancang soal literasi matematis, kemudian menyajikan kepada rekan sejawat untuk kemudian dapat ditularkan kepada siswa di sekolah masing-masing.

Selain itu, diberikan pula wawasan kepada guru mengenai contoh pembelajaran yang mengedepankan literasi dalam pembelajaran. Baik berupa video ataupun strategi dan pendekatan pembelajaran seperti apa yang bisa diterapkan di kelas sehingga bisa menarik minat siswa belajar.

\section{Hasil dan Diskusi}

Kegiatan dilakukan pada tanggal 21, 23, 24, 29 Agustus, 4 dan 11 September 2019. Pada pelatihan hari pertama peserta diberikan wawasan mengenai Literasi Sekolah. Pada sesi diskusi diketahui bahwa telah terjadi miskonsepsi makna literasi antara guru dengan konsep yang ada seperti yang dijelaskan [5], dimana literasi itu memiliki 3 tahap yaitu pembiasaan, pengembangan dan pembelajaran, sedangkan guru menganggap bahwa literasi berhenti sampai dengan tahap pembiasaan. Guru-guru sudah membiasakan siswa untuk membaca 15-30 menit setiap pagi, namun belum berhubungan dengan materi pada mata pelajaran di hari tersebut.

Pembahasan mengenai Literasi Matematika dilanjutkan pada hari kedua. Pembahasan berlangsung alot karena diintegrasikan diskusi selama penyampaian materi. Guru-guru diberikan materi dan contoh kasus yang berkaitan. Ketika diberikan soal, sebagian guru terlihat sangat antusias untuk menyelesaikan. Namun sebagian lagi tidak tertarik untuk membaca karena soal yang diberikan berupa soal cerita. Hal ini menunjukkan bahwa guru-guru pun belum terbiasa dengan literasi. Pada salah satu sesi, pemateri menyajikan soal yang menuntut kemampuan literasi-membaca dari apa yang tersedia namun tidak semua informasi disampaikan secara eksplisit, guru tampak emosi mengatakan bahwa materi yang disampaikan tidak sesuai untuk mereka. Padahal, pemateri memberikan pengantar untuk sampai kepada inti permasalahan. Ada masalah emosi yang harus dikontrol oleh guru selama pembelajaran. Jangan mengharapkan hasil yang lebih, selama belum bisa membaca. Uraian [6] bahwa guru gagal menterjemahkan bahasa soal ke bahasa 
matematika juga menyebabkan soal sederhana menjadi rumit.

Pada kesempatan berikutnya, dihadirkan siswa bersama guru yang sama-sama membahas mengenai leterasi matematis. Ada pemandangan menarik ketika siswa diperkenalkan literasi matematis. Beberapa siswa dapat menemukan poin-poin pentng yang tidak mampu ditemukan guru pada kesempatan sebelumnya. Hal ini menunjukkan kemampuan siswa yang tidak sepenuhnya berasal dari transferan ilmu yang diberikan guru, namun siswa bisa mengembangkan potensi dirinya untuk lebih baik. Guru cukup mengarahkan, tanpa menunjukkan jalan apa yang harus ditempuh. Biarkan siswa yang memutuskan akan memilih jalan yang mana.

Agenda kegiatan pada pertemuan selanjutnya adalah Merancang dan Memecahkan Soal Literasi Matematika SD. Disediakan waktu delapan jam untuk menyampaikan materi, diskusi dan perancangan soal. Pada kegiatan ini terlihat antusias yang tinggi dari para guru SD. Namun, kegiatan ini lebih banyak diisi dengan diskusi mengenai pembahasan soal.

Setelah guru cukup memahami konsep literasi matematis, diberikan materi mengenai bagaimana merancang dan memecahkan soal Literasi Berbasis PISA. Selain mampu memecahkan soal, guru juga dituntut dengan bimbingan pengabdi untuk membuat soal sendiri sejenis.

Pada kesempatan terakhir, dilakukan ujicoba terbatas atas soal yang telah dirancang dengan membahas bersama siswa. Kegiatan yang diberi judul Bermain bersama Siswa dan Soal Literasi PISA, cukup menarik minat siswa dalam belajar. Siswa tertarik untuk belajar entah karena memang sudah mulai mencintai materi, atau karena ada hadiah yang disediakan bagi yang berhasil menyelesaikan maslaah. Namun demikian, kita bersama harus memperhatikan hal-hal kecil untuk mencapai sesuatu yang lebih besar.

\section{Kesimpulan}

Guru sudah memiliki pengetahuan mengenai konsep literasi dan literasi matematis secara khusus serta mampu merancang soal berbasis literasi. Selain itu, siswa juga cukup tertarik dengan pembelajaran yang dilakukan. Untuk kesempatan berikutnya, diharapkan lebih banyak pembelajaran yang memperhatikan hal-hal kecil yang meningkatkan minat belajar, baik siswa ataupun guru.

\section{Ucapan Terima Kasih}

Penulis mengucapkan terimakasih kepada Universitas Negeri Padang yang telah memberikan dana untuk kegiatan PkM ini. Terimakasih juga disampaikan kepada guru dan siswa di Gugus III Kecamatan Guguak atas partisipasi aktifnya dan Dinas Pendidikan Kabupaten Lima Puluh Kota yang telah memfasilitasi kegiatan.

\section{Pustaka}

[1] Johar R. Domain Soal PISA untuk Literasi Matematika. Jurnal Peluang, Volume 1, Nomor 1, Oktober; 2012.

[2] Jufri LH. Penerapan Double Loop Problem Solving untuk Meningkatkan Kemampuan Literasi Matematika Level 3 pada Siswa Kelas VIII SMPN 27 Bandung. LEMMA 2(1); 2015.

[3] Khikmiyah F dan Midjan. Pengembangan Buku Ajar Literasi Matematika untuk Pembelajaran di SMP. Jurnal Silogisme: Kajian Ilmu Matematika dan Pembelajarannya. Universitas Muhammadiyah Gresik 1(2); 2016.

[4] Sari RHN. Literasi Matematika: Apa, Mengapa dan Bagaimana. Seminar Nasional Matematika dan Pendidikan Matematika. Yogyakarta: Universitas Negeri Yogyakarta; 2015.

[5] AHMAD, Defri; Syafriandi; JAZWINARTI, Jazwinarti. Training and Workshop to Apply Mathematical Literacy in Classroom for Mathematics Teachers in Dharmasraya. Pelita Eksakta, [S.1.], v. 2, n. 1, p. 48-53, apr. 2019. ISSN 2615-0719. Available at: $<$ http://pelitaeksakta.ppj.unp.ac.id/index.php/pelita eksakta/article/view/62>. Date accessed: 22 oct. 2019. doi: https://doi.org/10.24036/pelitaeksakta/ vol2-iss 1/62.

[6] Syafriandi; FITRIA, Dina. Analysis of Teacher's Competence About Mathematics Materials for National Final Examination. Pelita Eksakta, [S.1.], v. 1, n. 1, p. 20-26, mar. 2018. ISSN 26150719. Available at: <http://pelitaeksakta.ppj.unp. ac.id/index.php/pelitaeksakta/article/view/5>.

Date accessed: 22 oct. 2019. doi: https://doi.org/10.24036/pelitaeksakta /vol1-iss1/5 